NASA Technical Memorandum 106291

AIAA-93-2228

\title{
Plasma Contactor Technology for Space Station Freedom
}

Michael J. Patterson and John A. Hamley

Lewis Research Center

Cleveland, Ohio

Timothy Sarver-Verhey, George C. Soulas, and James Parkes

Sverdrup Technology, Inc.

Lewis Research Center Group

Brook Park, Ohio

Wayne L. Ohlinger

Georgia Technical Research Institute

Atlanta, Georgia

Michael S. Schaffner

Cleveland State University

Cleveland, Ohio

and

Amy Nelson

Purdue University

West Lafayette, Indiana

Prepared for the

29th Joint Propulsion Conference and Exhibit cosponsored by AIAA, SAE, ASME, and ASEE

Monterey, California, June 28-30, 1993

\section{NASA}




\title{
Plasma Contactor Technology for Space Station Freedom
}

\author{
Michael J. Patterson* and John A. Hamley* \\ National Aeronautics and Space Administration \\ Lewis Research Center \\ Cleveland, Ohio \\ Timothy Sarver-Verhey, George C. Soulas, and James Parkes \\ Sverdrup Technology, Inc. \\ Lewis Research Center Group \\ Brook Park, Ohio \\ Wayne L. Ohlinger \\ Georgia Tech Research Institute \\ Georgia Institute of Technology \\ Atlanta, Georgia \\ Michael S. Schaffner \\ Department of Electrical Engineering \\ Cleveland State University \\ Cleveland, Ohio \\ Amy Nelson \\ Department of Physics \\ Purdue University \\ West Lafayette, Indiana
}

\begin{abstract}
Hollow cathode plasma contactors have been baselined for Space Station Freedom (SSF) to control the electrical potentials of surfaces to eliminate/mitigate damaging interactions with the space environment. The system represents a dual-use technology which is a direct outgrowth of the NASA electric propulsion program and in particular the technology development effort on ion thruster systems. Specific efforts include optimizing the design and configuration of the contactor, validating its required lifetime, and characterizing the contactor plume and electromagnetic interference. The plasma contactor subsystems include the plasma contactor unit, a power electronics unit, and an expellant management unit. Under this program these will all be brought to breadboard and engineering model development status. New test facilities have been developed, and existing facilities have been augmented, to support characterizations and life testing of contactor components and systems. This paper discusses the magnitude, scope, and status of the plasma contactor hardware development program now underway and preliminary test results on system components.
\end{abstract}

\section{Introduction}

The Space Station Freedom (SSF) power system is designed with high voltage solar arrays which operate at output voltages of typically $140-160$ volts. The power system is configured with a "negative ground" that electrically ties the habitat modules, structure, and radiators to the negative tap of the solar arrays. The solar arrays represent a large surface area for electron current collection from the space plasma due to exposed surfaces along the solar cell edges. These surfaces are at positive potentials, relative to the negative ground, up to the maximum array potential. The exterior surfaces tied to the negative array tap, however, are insulated from the space plasma because the radiators are coated with nonconducting high-emissivity paint and the habitat modules are coated with an anodized layer for thermal control. This electrical configuration and the plasma current balance that results will cause the habitat modules, structure, and radiators to float to voltages as large as -

Copyright $\odot 1993$ by the American Institute of Aeronautics and Astronautics, Inc. No copyright is asserted in the United States under Title 17, U.S. Code. The U.S. Government has a royalty-free license to exercise all rights under the copyright claimed herein for Government purposes. All other rights are reserved by the copyright owner.

*Aerospace Engineer, Member AIAA 


\section{PLASMA CONTACTOR TECHNOLOGY FOR SPACE STATION FREEDOM}

$120 \mathrm{~V}$ with respect to the ambient space plasma (Figure $1)^{1}$

As a result of the large negative floating potentials, there exists the potential for deleterious interactions of SSF with the space plasma. These interactions may include arcing through insulating surfaces (both spontaneous and debris induced) and sputtering of conductive surfaces due to acceleration of ions by the spacecraft plasma sheath. Both of these processes result in changes in surface material properties, destruction of coatings, and contamination of surfaces due to redeposition. Additionally there is concern that the arcing will result in conducted and radiated electromagnetic interference (EMI) and/or SSF power system current surges and power loss.

A variety of solutions have been identified to alleviate/eliminate the potentially deleterious interactions with the space plasma, including modifying the solar cell design or surface coatings and/or adding a plasma contactor system. Each of these options was proposed as a means of either increasing the impedance for electron collection on the solar array or increasing the ion conduction of the plasma sheath surrounding the structure. Both modifications would drive the negative potential surfaces closer to space plasma potential and possibly below the threshold voltage for arcing to occur. Based on potential effectiveness and impact on the SSF flight program cost and schedule, a decision was made in April 1992 to baseline a plasma contactor system on SSF as the solution to alleviate SSF/space plasma interactions. ${ }^{2}$

NASA-Lewis Research Center (LeRC)/Work Package (WP) 4 was therefore directed to initiate a plasma contactor development program as part of the SSF electrical power system.

A plasma contactor is a device which can control the spacecraft potential relative to the local space plasma potential by establishing a low-impedance plasma bridge. There are a variety of plasma contactor types which vary in the level of design maturity, effectiveness, complexity, and operational requirements. Contactor types include electron and ion guns; passive conducting surfaces; neutral gas releases; and a variety of plasma sources including pulsed magnetoplasma dynamic (MPD) devices ${ }^{3}$, and hollow cathode plasma sources. ${ }^{4}$

For the SSF application, efficient and rapid emission of high electron currents is required by the plasma contactor under conditions of variable and uncertain current demand. A hollow cathode plasma contactor is well suited for this application. Hollow cathode plasma contactors have a demonstrated low impedance and high current capability and they operate in a self-regulating emission control mode. They are acknowledged to be the optimal charge-control concept for electrically active spacecraft by the spacecraft-charging community. ${ }^{5-7}$ Additionally, this type of contactor device has demonstrated potential control of SSF structures (a 1/82 scale solar array wing, a full-sized solar array circuit, and small scale anodized plates) in ground testing at NASA-LeRC under simulated space plasma conditions. The hollow cathode plasma contactor effectively clamped the electrically floating structures to within a few volts of plasma ground, prevented arcing on the structure, and operated in a stable manner.

The hollow cathode is the key element of the hollow cathode plasma contactor. Hollow cathodes have been developed to an advanced state of technology readiness for ion propulsion. In ground tests they have demonstrated high emission currents (> $30 \mathrm{~A}$ ), and long lifetimes, with modest $(<100 \mathrm{~W})$ power requirements. Hollow cathode plasma sources have demonstrated versatile and effective operation as plasma contactors in ground testing of various devices. This testing includes plasma bridge neutralizers for ion thrusters, plasma contactor demonstration experiments for the electrodynamic tether, ${ }^{8}$ and the aforementioned SSF structure potential control experiments.

Hollow cathodes have also been flown in space as components of ion propulsion systems and spacecraft charging/charge-control systems, including ATS- $6^{9}$, SERT-II ${ }^{10}$, SCATHA ${ }^{11}$, and SCSR- $1^{12}$ flight experiments. Demonstrated capabilities in space tests include lifetimes of $10,000 \mathrm{~h}$ and $>300$ restarts. $^{13}$ NASA flight experiments have demonstrated hollow cathode plasma contactors to be effective in controlling both spacecraft frame negative charging ${ }^{10}$ and differential charging. ${ }^{9}$ Hollow cathodes have been operated in space under a variety of orbital/environmental conditions, on spacecraft including an Agena vehicle, communication satellites, and the space shuttle. Environments include those of lowEarth orbits, sun-synchronous high inclination orbits, and geosynchronous orbits.

Most of the above hollow cathode development was accomplished with mercury as the hollow cathode expellant, or "working fluid." For a variety of reasons, including spacecraft contamination, present hollow cathodes preferentially utilize inert gases (primarily xenon) as the expellant. Subsequent to the transition from mercury to xenon in the early 1980 's, there have been, and continue to be, failures of hollow cathodes in the United States, in Europe, and in Japan. These have impacted both research and development activities and flight programs. The failures have apparently been primarily due to inadequate procedures and protocols to control contamination during fabrication, assembly, testing, storage, handling, and operation of the cathodes. To date only one extended-duration test of a xenon hollow cathode at 


\section{PLASMA CONTACTOR TECHNOLOGY FOR SPACE STATION FREEDOM}

high (> $1 \mathrm{~A}$ ) emission currents has been reported which is free of contamination effects. ${ }^{14}$

The operational requirements for the SSF plasma contactor are extremely demanding and go well beyond the current state-of-the-art for xenon hollow cathodes. These requirements, as discussed in the next section, include $\geq 13,000 \mathrm{~h}$ lifetimes and electron emission currents that vary from a few hundred milliamperes to up to $10 \mathrm{~A}$ with complex, time-dependent dynamic response characteristics. Additionally, the plasma contactor is on a crewed vehicle and is considered a mission-critical system requiring single-fault tolerant reliability. These considerations dictated initiation of a plasma contactor development effort, including an in-house hardware definition and testing task. The first results of this inhouse effort are reported in this paper.

\section{Development Objectives}

The in-house hardware definition and testing task is responsible for: (1) parametric testing of hollow cathodes and plasma contactor system components, (2) establishing design requirements for a long endurance plasma contactor system, and (3) acquiring long term endurance data for components and systems to support flight hardware development. The specific hardware development objectives include:

- Development of the plasma contactor unit (PCU) to engineering model status. The PCU, which consists of the hollow cathode plasma source and mounting hardware, will be brought to a sufficient level of maturity as to make the flight hardware development a build-to-print effort.

- Development of the power electronic units (PEU) to breadboard level. The PEU consists of the power supplies for operation of the PCU and the gas feed system valves, and a controller for command and telemetry. The flight PEU could be developed with any one of several topologies, and the approach of bringing the PEU to only a breadboard level in the in-house effort allows for flexibility in the flight hardware design. Areas being addressed in the PEU development include definition of the critical interfaces and control functions with the PCU, gas feed system, and with SSF, and identification of control laws and requirements for autonomous, faulttolerant system function.

- Development of the expellant management unit (EMU) to breadboard level. The EMU consists of a high-pressure gas storage tank, the xenon expellant, and gas feed system components including lines, valves, and regulators. Areas being addressed in the EMU development include definition of PCU/xenon flow control requirements and contamination control requirements and limits.

Table I lists the technology issues associated with each of the major plasma contactor system (PCS) components, and it identifies the functions and hardware phase each component will be developed to under the in-house hardware definition and testing task. In addition to these specific hardware objectives, numerous performance, integration, and lifetime tests will be conducted on components, subsystems, and systems to verify functionality and support the flight hardware development task. Figure 2 shows a conceptual design lay-out for a plasma contactor system. The following sections discuss the status of the in-house hardware definition and testing task.

\section{Operational Requirements}

Under the directive provided to WP 4 to develop a plasma contactor for SSF, the single primary design requirement is stated that "the Space Station structure floating potential at all points on the Space Station shall be controlled to within 40 volts of the ionospheric plasma potential using a plasma contactor." ${ }^{n 15}$ The 40 volt potential is estimated to be below the threshold potential for arcing to occur. It is estimated that induced potentials on the station, caused by the structure cutting through the Earth's magnetic field, may be as high as 20 volts. ${ }^{16}$ This reduces the operating margin available to the plasma contactor to approximately 20 volts to satisfy the 40 volt limit.

The plasma contactor system must be single-fault tolerant because the potential control function is considered mission critical. This requirement will be satisfied by having 2 plasma contactor systems on-board SSF, one operating and one as a back-up. Each system will have a single-string PCU-PEU-EMU architecture and will be housed in separate orbit replaceable unit (ORU) avionics boxes, with separate interfaces to SSF. Additional requirements for the PCS include an operating lifetime of $13,000-17,500$ hours and instrumentation to monitor the PCU emission, or plasma return, current. ${ }^{17}$

The electron emission current requirements for the PCU to control SSF potentials unfortunately cannot be characterized by a "typical" emission profile versus time. However bounds on the requirements may be drawn from the following considerations: ${ }^{18}$

- Active emission to the space plasma of electron current at least matching the net electron current collected on the spacecraft (referred to as "Clamping" mode) is required during approximately one-third of the orbital period, beginning at dawn and going through noon when the solar arrays are illuminated, generate power, and face in the ram direction. During the remainder of the orbital 


\section{PLASMA CONTACTOR TECHNOLOGY FOR SPACE STATION FREEDOM}

period the plasma contactor unit will remain on, operating in an "Idle" mode.

- The plasma contactor system is scheduled to be launched in-place on mission build (MB) 4, which is the launch of the main truss segment. As the space station evolves during the build-up phase, additional solar array wings will be added until the station is completely assembled by MB 17 with a total of 6 wings. As the station is undergoing construction, and as its flight attitude is changed with respect to the velocity vector, the peak emission current required will increase due to higher generated power levels and larger surface areas exposed to electron current collection. The maximum required emission currents are expected to scale as the array area. Hence, the anticipated peak emission current at the permanently-manned capability (PMC) at MB 17 with 6 solar array wings is anticipated to be 6 times greater than that required during MB 4 which has one deployed wing.

- The peak emission current may vary by a factor of two from orbit to orbit and by a factor of five from day to day, during any portion of the station operations (build-up or PMC).

- Models describing the required dynamic behavior of the emission current - principally the rise and decay times during active emission - cannot time-resolve the current variations below approximately one minute intervals with any certitude. However, large variations $(>10 \%$ ) in required emission current are not expected to be on time scales less than tens to hundreds of seconds, except during entry into and exit from eclipse periods.

- Any predicted emission current is estimated to have a factor of four uncertainty due to the combined uncertainties in estimating the station surface area for electron current collection and predicting the ambient space plasma properties.

Because of the complex time-dependent emission current requirements and large associated uncertainties, constraints and compromises in the design and testing of the PCU must be imposed. The over-riding requirements are to satisfy the potential control requirement and maximize expectations for long life by implementing a simple, robust design. While minimizing consumables (xenon gas, power, etc.) is important, this is secondary to potential control and life.

From modelling results that quantify contactor emission demand over various flight modes, a requirement that the PCU be capable of emitting $10 \mathrm{~A}$ of electron current to the space plasma has been derived. This and other major derived operational requirements for the SSF PCS are listed in Table II. Figure 3 shows the required timedependent electron emission current predicted for the plasma contactor unit during MB 6 for a single orbit under solar maximum conditions. ${ }^{19}$

\section{System Design}

As identified in Table I, the SSF plasma contactor system consists of four components, or subsystems. These are the PCU, PEU, EMU and ORU. The PCU will achieve potential control of SSF by having the cathode emitting potential of the PCU electrically tied to the negative single-point ground of the SSF main truss segment, as illustrated in Figure 4. This arrangement allows for the emission current to rapidly track the variable and uncertain current demand, at fixed PCU input power conditions. Single-fault tolerance will be satisfied by having two completely independent, redundant plasma contactor systems, co-located on the main truss segment. ${ }^{17}$ The PCS components are described below in more detail.

\section{Plasma contactor unit -}

A hollow cathode plasma source operating on xenon gas has been selected as the basic design approach for the PCU. The PCU contains a hollow cathode consisting of a low-work function insert for electron emission, a body tube with a heater, and an electrical isolator. Additional components include anode(s), expellant injector(s), and possibly magnets to augment ionization efficiency and reduce the xenon gas consumption rate. The major PCU components, including the hollow cathode assembly, are all derived from mature technology developed for xenon ion thrusters.

The operation of the PCU can be characterized by several parameters which are critical to its performance and lifetime. These include the clamping voltage (the potential difference between the PCU hollow cathode and space plasma), cathode to anode voltage and current, xenon consumption rate, emission current (net current to space plasma), and input power. Another important parameter is the ion production rate necessary to sustain the electron emission current at low clamping voltage.

The plasma contactor hollow cathode requires a heater to raise the cathode temperature so as to remove contaminants from the cathode insert surface and to facilitate ignition. Although the plasma contactor will be operated continuously, the hollow cathode emission current to the space plasma will vary throughout the orbit, thereby thermally cycling the cathode and heater. A long-life heater that can withstand thousands of thermal cycles is important to ensure high reliability in restarting a contactor.

Power electronics unit -

The power electronics unit (PEU) for the plasma 


\section{PLASMA CONTACTOR TECHNOLOGY FOR SPACE STATION FREEDOM}

contactor system conditions power from the SSF 120 VDC main power bus, converting it to the levels necessary for proper plasma contactor operation. Additional PEU functions include cathode activation, discharge ignition and maintenance, and control of the expellant management unit (EMU). Commands from SSF are input through a command and telemetry interface, which also transmits values of various parameters from the PCU, PEU, and EMU to the SSF data system. A block diagram of the PEU appears in Figure 5.

The PCU controller, which is embedded within the PEU, provides the necessary logic to interpret incoming commands from the SSF data management system (DMS) and carry out appropriate response procedures. Commands are input to the PEU via discrete digital input/output lines from the nearest SSF multiplexer/demultiplexer (MDM). Analog telemetry data are also passed directly to the controller for internal use and to the MDM for digitization and transmission with the other SSF data. Control of the cathode heater and discharge power supplies and EMU valves is accomplished using sequential and combinational logic circuitry. The PCU controller also provides the output setpoints for the cathode heater and discharge supplies.

The 120 VDC power is brought into the PEU through an electromagnetic interference (EMI) filter to ensure interference isolation between the PEU and the SSF power bus. The filtered power directly drives the control power converter, which is active at all times. This converter provides low voltage control power for the other power supplies in the PEU and the PCU controller. All power converters in the PEU are designed with isolated transformer topologies to ensure compatibility with the SSF power system grounding requirements.

The cathode heater supply provides power to the heating element of the cathode during activation and the preheat phase of the ignition procedure. The heater is unpowered during normal cathode emission. The output of the power supply is regulated in a constant current mode, with a maximum output of $12 \mathrm{ADC}$, and an absolute maximum output voltage of 15 VDC. The output current is set via a $0-2.5 \mathrm{~V}$ reference signal from the PCU controller.

The discharge power supply ignites and maintains the discharge between the hollow cathode and the anode of the plasma contactor. The power supply is capable of a maximum $28 \mathrm{~V}$ steady state output voltage at a nominal current of $2 \mathrm{~A}$. Output current is regulated to within $1 \%$ of the setpoint with a ripple of $5-10 \%$. Discharge ignition requires that the cathode first be heated to a sufficiently high temperature with the cathode heater. The 28 VDC discharge open circuit voltage and a high voltage pulse train are then applied to the anode. The nominal pulse parameters are an amplitude of $350 \mathrm{~V}$, a duration of $50 \mu \mathrm{S}$, and a repetition rate of $10-100 \mathrm{~Hz}$. Cathode heater power and the pulse train are automatically removed when the discharge current exceeds 500 $\mathrm{mA}$.

The auxiliary power supply provides a regulated 28 VDC output, which is used to power the xenon tank heater, the EMU valves, and the ignition circuit in the discharge supply. The maximum output capacity of the auxiliary power supply is $28 \mathrm{VDC}$ at $50 \mathrm{~W}$.

\section{Expellant management unit -}

The EMU stores the xenon expellant as a gas under high pressure, and controls and regulates its flow to the plasma contactor. A critical concern in its design is controlling the level of reactive contaminants that reach the plasma contactor hollow cathode. These contaminants are present in the gas as a result of the production and tanking of the xenon and from outgassing of feed system elements. One embodiment of the PCS EMU is conceptually shown in Figure 6. Final design and interface requirements for the EMU will be derived from the design of the PCU.

\section{Technical Approach}

This section describes the technical approach implemented in the hardware development and testing task, involving work at both LeRC and Georgia Technology Research Institute (GTRI). The appendix discusses in detail the various test facilities developed at LeRC in support of this program.

An extensive series of tests of all PCS subsystems is underway at NASA-LeRC. These tests include hollow cathode and other PCU component performance and wear tests of successively longer duration to resolve cathode design, materials, and contamination issues. PCU performance, design optimization, and life tests are being conducted under appropriate operating and environmental conditions. System-level integration tests and assessments of plume, optical, and EMI emissions of the contactor unit and system are being carried out. Also, PEU development and PCU-PEU integration efforts are proceeding, and EMU requirements are being defined and validated.

The objective of the GTRI effort is to provide quantitative information regarding the interaction of the low work function impregnated insert of the plasma contactor hollow cathode with the ambient environment in which it is manufactured, handled, assembled, and stored. Also under evaluation is the insert's interaction with the operating environment of the cathode including effects of the expellant gas, impurities contained in it, and the 


\section{PLASMA CONTACTOR TECHNOLOGY FOR SPACE STATION FREEDOM}

thermal conditions prevailing during all modes of operation. These studies will define critical specifications for xenon gas purity, the cathode insert activation procedure, and control of ambient conditions during PCU assembly and pre-launch storage and handling. This program also addresses the development of appropriate specifications for the fabrication of the flight inserts. This work is in three distinct areas. Each is briefly reviewed below.

- Development of Specifications for Handling and Activation - The insert impregnant materials are sensitive to exposure to sea-level ambient atmosphere. Available information indicates that the impregnant absorbs and reacts with atmospheric water vapor and carbon dioxide. However, there is no detailed information available regarding the rate, extent and consequences of such reactions. The reactions of the impregnant compounds are being studied using analytical techniques including $x$ ray diffraction and thermal analysis (both differential and thermogravimetric). Also under investigation is the possibility that the hydrolyzed and carbonated impregnant compounds may react with the tungsten matrix material of the insert at temperatures below the operating temperature, e.g., during cathode activation.

- Microanalysis of Cathode Inserts - This effort concentrates on analyzing the inserts in detail, both asmanufactured and after operation. The as-manufactured components are being evaluated to define necessary specifications for acceptable inserts. Inserts will be studied after operation to identify problems caused by operational factors to which the inserts are known to be sensitive, such as xenon gas contamination or excessive operating temperature. Such factors are of vital importance in assuring adequate cathode lifetime with tolerable performance degradation. The analytical techniques employed in the insert analysis work include scanning electron microscopy, energy dispersive $\mathrm{x}$-ray analysis, $\mathrm{x}$ ray diffraction, and optical microscopy.

- Development of Fabrication Specifications - Specifications for the fabrication of the flight inserts are being defined on the basis of past experience and the present development effort. All critical chemical and physical characteristics of the insert are under review and will be defined to the extent necessary to assure procurement of a reliable and reproducible product. This effort also will define specifications on critical manufacturing processes and necessary documentation of materials and procedures.

\section{Hardware Development Status and Preliminary Test Results}

- Hollow cathode and plasma contactor unit - Progress has been made in both developing the hollow cathode assembly for the plasma contactor unit, and in designing the engineering model plasma contactor unit. A series of tests has been conducted to develop and validate the hollow cathode assembly design. These tests include measuring critical cathode temperatures as a function of the emission current in order to properly dimension the cathode and conducting long-duration wear tests to develop and verify contamination control requirements and cathode operating protocols. The critical dimensions and materials for the flight PCU hollow cathode have now been established. The wear tests successfully conducted to date include one in which over 3000 hours of operation at $12 \mathrm{~A}$ emission current has been accumulated (see Figure 7). Components of the hollow cathode assembly that have been developed to engineering model status include the xenon expellant isolator and the cathode heater. Several engineering model heaters have been fabricated and one has been life tested for more than 5000 on/off thermal cycles with no change in performance or life-critical characteristics. Figure 8 shows typical performance data for the engineering model heater. Process specifications have been established for the fabrication, inspection, and acceptance testing of several cathode components, including the heater.

Activities at GTRI have resulted in definition of cathode insert materials and process specifications. Additionally, impregnant samples have been exposed to a range of temperature and humidity conditions and the rates and extent of the reactions determined. Hydration weight gains as large as $40 \%$ have been indicated. These results have required modification of the procedure which prepares the flight cathodes for initial on-orbit operation and in the process expels the absorbed water.

The performance of approximately 15 different prototype plasma contactor units has been measured to determine the critical design and operating parameters governing the PCU's potential control characteristics, and to define appropriate ground test procedures. Figures 9 and 10 show prototype plasma contactor units mounted on a test stand and operating in a high emission current clamping mode, respectively. Data from these tests were sufficient to quantify system-level impacts of PCU operation and to select a baseline PCU design. A PCU having the selected geometry has demonstrated all performance requirements for the SSF contactor during short-duration testing under conditions which are consistent with the required 13,000 - 17,500 hour operational lifetime. Figure 11 shows a typical current-voltage emission characteristic for the PCU. Subsequent tests have established critical design dimensions, required input power levels, and xenon consumption rates. PCU optical emissions in the $300-900$ micron wavelength range and radiated electromagnetic emissions in the $10 \mathrm{kHz}-40$ $\mathrm{GHz}$ frequency range have also been characterized. The 


\section{PLASMA CONTACTOR TECHNOLOGY FOR SPACE STATION FREEDOM}

results indicate no major radiated EMI issues with SSF systems. Additionally, an engineering model drawing package for the PCU is near completion and fabrication of the engineering model design has been initiated.

- Power electronics unit - Cathode heater and discharge supplies have been fabricated and integrated with a flight-rated control power converter to form the breadboard PEU. The overall efficiency of the cathode heater supply was measured to be 0.82 for a $10 \mathrm{~A}, 100 \mathrm{~W}$ output condition. The discharge supply efficiency was 0.70 for an output of $2 \mathrm{~A}$ at $56 \mathrm{~W}$. These low efficiencies are primarily due to the low output voltages and power levels of these supplies, together with the control power losses for the power stages, which are significant when compared to the overall power.

The breadboard PEU has been integrated with a prototype PCU. The PEU successfully demonstrated cathode preheat, ignition, and steady state operation of the PCU at conditions up to $10 \mathrm{~A}$ net electron emission current. The fabrication of several additional breadboard PEU's has been initiated to support the development program.

The breadboard PEU is being modified to include a controller and an auxiliary power converter (see Fig. 5). The controller will be a single-board microprocessor and will contain the digital input/output (I/O), analog I/O, and timers. The digital $\mathrm{I} / \mathrm{O}$ communicates with the $\mathrm{MDM}$, and the analog $\mathrm{I} / \mathrm{O}$ is used for power supply control and local data monitoring. The timers control PCU hollow cathode activation and startup procedures. The auxiliary power converter will be used to provide power to the breadboard EMU and to the PCU starting circuit.

- Expellant management unit - Critical issues associated with the development of the EMU include contamination control of the xenon expellant, and flow control of the expellant during cathode activation, startup, and steady-state operation. These issues are under active investigation in the hollow cathode and PCU development phases of the program and will require resolution prior to fabrication of the breadboard EMU. Figure 12 shows the type of EMU presently employed for controlled delivery of xenon to the hollow cathode and plasma contactor test articles for performance and lifetime assessments. The breadboard EMU is essentially identical in function to the test systems with the exception that the latter are not interfaced with the PEU.

\section{Concluding Remarks}

Space Station Freedom has baselined hollow cathode plasma contactor systems for potential control of space station structures to mitigate possible damaging interactions with the space plasma. NASA-LeRC/Work
Package 4 has been directed to initiate a plasma contactor development program as an integral part of the SSF electrical power system. In support of this activity, an in-house hardware definition and testing program is being conducted to establish design requirements for the SSF plasma contactor system and acquire performance and endurance data for components of the PCS. Under this program, the plasma contactor unit is being developed to engineering model status and the PEU and EMU to breadboard models.

Progress has been made in key areas. Several new cryopumped test facilities have been developed, and existing facilities have been augmented, to support characterizations and life testing of components and systems. The PCU hollow cathode assembly design has been completed and validated via performance tests and long-duration wear tests of hollow cathodes and heaters. Additionally test procedures and materials and process specifications for critical cathode components have been developed. Prototype plasma contactor units have been built and tested over the required emission current ranges, and several have met all performance requirements for the SSF contactor under operating conditions expected to allow meeting the 13,000 - 17,500 hour operating lifetime requirement. Electromagnetic emissions radiated by the PCU have been measured and pose no major compatibility issues with SSF systems. The PCU engineering model design selected for SSF has been based on the results of this test program. The power electronics unit for the PCU has been breadboarded and successfully integrated with a prototype PCU, demonstrating all required flight operating modes. Future testing will evaluate the performance and lifetime of the engineering model PCU and the integrated breadboard system.

\section{Acknowledgements}

The support of the SSF Plasma Contactor Office/Photovoltaic Power Module Division, and specifically Robert Corrigan, Program Manager, is gratefully acknowledged. Additionally the authors would like to express their appreciation to the modeling and analysis team lead by Dr. Carolyn Purvis, Chief of the NASALeRC Space Environment Effects Branch, for many helpful discussions. Fabrication and test support provided by Robert Butler, George Jacynycz, Fred Jent, David Lilly, Bernard Loyer, Craig Nelson, Mike Pastel, Eugene Pleban, Mike Perez, Gerald Schneider, Larry Schultz, David Wolford, and Peggy Yancer is gratefully acknowledged.

\section{References}

${ }^{1}$ Personal communication, Katz, I., S-Cubed Division of Maxwell Labs, San Diego, CA, October 1992.

${ }^{2}$ Moorehead, R.W., Deputy Director, Space Station Freedom Program and Operations, communication to 


\section{PLASMA CONTACTOR TECHNOLOGY FOR SPACE STATION FREEDOM}

Work Packages 1-4 Directors, dated April 3, 1992.

${ }^{3}$ Ijichi, K., Harada, H., and Kuricki, K., "MPD Arcjet System for Space Experiment with Particle Accelerator (SEPAC)," AIAA Paper No. 79-2072, October 1979.

${ }^{4}$ Beattie, J.R., et al., "System Performance of ATLAS Plasma Contactor," AIAA Paper No. 90-2568, July 1990.

${ }^{5}$ Duncan, W., et al., "Final Report Ad Hoc Orbiter Charging Committee for the TSS-1 Mission," Universities Space Research Association Report, Nov. 8, 1985.

${ }^{6}$ Kolecki, J.C., "Electrodynamic Interactions, Executive Summary," Proceedings of the 2nd Biennial Workshop, Applications of Tethers in Space, Venice, Italy, Oct. 1517, 1985.

${ }^{7}$ Burch, J.L., Southwest Research Institute Letter Conveying Charge Neutralization Workshop Resolution, Sept. 9, 1985.

${ }^{8}$ Patterson, M.J. and Wilbur, P.J., "Plasma Contactors for Electrodynamic Tether," NASA TM-88850, September 1986.

${ }^{9}$ Olsen, R.C. and Whipple, E.C., "Active Experiments in Modifying Spacecraft Potential: Results from ATS-5 and ATS-6," NAS 5-23481 Final Report, May 1977.

${ }^{10}$ Jones, S.G., Staskus, J.V., and Byers, D.C., "Preliminary Results of SERT II Spacecraft Potential Measurements Using Hot Wire Emissive Probes," AIAA Paper No. 70-1127, August 1970.

${ }^{11}$ McPherson, D.A., Cauffman, D.P., and Scheber, W.R., "Spacecraft Charging at High Altitudes: SCATHA Satellite Program" Journal of Spacecraft and Rockets, Vol. 12, Oct. 1975, pp. 621-626.

${ }^{12}$ Cohen H., et al., "The Sounding Rocket Flight of a Satellite Positive Ion Beam System," ALAA Paper No. 792068, Oct. 1979.

${ }^{13}$ Kerslake, W.R. and Ignaczak, L.R., "Development and Flight History of SERT II Spacecraft," AIAA Paper No. 92-3516, July 1992.

${ }^{14}$ Sarver-Verhey, T.R., "Extended-Testing of Xenon Ion Thruster Hollow Cathodes," ALAA Paper No. 923204, July 1992.

${ }^{15}$ Directive SSCBD: BM003057, paragraph 3.1.3.2.1.8 to SSP 30000, dated December 4, 1992.

${ }^{16}$ Personal communication, Katz, I., S-Cubed Division of Maxwell Labs, San Diego, CA, August 1992.

${ }^{17}$ Personal communication, Corrigan, R., NASA-Lewis Research Center, December 1992.

${ }^{18}$ Personal communication, Katz, I., S-Cubed Division of Maxwell Labs, San Diego, CA, December 1992.

${ }^{19}$ Personal communication, Jongeward, G., S-Cubed Division of Maxwell Labs, San Diego, CA May 1993.

\section{Appendix}

Test stands developed for PCS testing -

The following test stands have been built up at LeRC for testing components and subsystems of the PCS. All the facilities employed for life or wear testing can operate autonomously for periods of several months in duration.

- Hollow cathode wear test stand - This facility is presently operational and is used for long-duration wear tests of xenon hollow cathodes to evaluate contamination control requirements for the EMU. Testing with this facility also has obtained cathode temperature information critical to lifetime assessments and to cathode sizing requirements for the PCU. The facility has a single test port (to accommodate the hollow cathode) which is attached to a six-way vacuum cross evacuated with a helium refrigerator cryopump (see Figure A1). The facility has a xenon pumping speed of approximately 1100 $\ell / s$ and can be operated for several thousands of hours before regeneration of the cryogenic pumping surface is required. The facility has a base pressure of approximately $1.3 \times 10^{-5} \mathrm{~Pa}\left(1.0 \times 10^{-7}\right.$ torr $)$ and an operating pressure of $1.5 \times 10^{-2} \mathrm{~Pa}\left(1.1 \times 10^{-4}\right.$ torr $)$ under typical cathode operating conditions.

- Heater test stand - This facility (see Figure A2) is designed for testing the performance and cyclic-life of the PCU hollow cathode's heater assembly. The vacuum chamber consists of a $0.3 \mathrm{~m}$ diameter by $0.3 \mathrm{~m}$ long stainless steel cylinder evacuated with a turbomolecular pump. The typical base pressure of the facility is $1.3 \mathrm{x}$ $10^{-4} \mathrm{~Pa}\left(1.0 \times 10^{-6}\right.$ torr $)$. The stand is designed to accommodate concurrent life testing of up to 3 heaters.

- Hollow cathode and PCU life test stand - This facility is presently operational and in use to conduct life testing of both hollow cathodes and plasma contactors. Fully automated life testing of up to six hollow cathodes or four plasma contactors can be concurrently conducted in it. The vacuum chamber is approximately $1 \mathrm{~m}$ in diameter by $1.5 \mathrm{~m}$ in length and has two $0.3 \mathrm{~m}$ test ports which can be isolated from the main chamber by gate valves (see Figures $\mathrm{A} 3$ and $\mathrm{A} 4$ ). The vacuum chamber is equipped with a $0.9 \mathrm{~m}$ diameter helium refrigerator cryopump attached to one end, providing a xenon pumping speed of approximately $15,000 \mathrm{\ell} / \mathrm{s}$. The facility's base pressure is approximately $1.3 \times 10^{-6} \mathrm{~Pa}(1.0$ x $10^{-8}$ torr).

- Plasma contactor wear test stand - This facility is presently under construction and will be used to define and verify conditions for PCU hollow cathode ignition. Its design and pumping train are similar to those of the hollow cathode wear test facility shown in Figure A1, and it will accommodate up to three plasma contactors for cyclic ignition tests.

- Plasma contactor and system integration stand - This new vacuum chamber facility, fabricated of aluminum, is 
$2.1 \mathrm{~m}$ in diameter and $4.3 \mathrm{~m}$ long. Presently under construction, the facility will be used to conduct detailed PCU-PEU integration tests and PCS performance and lifetime assessments. The pumping train includes a twostage blower system backed up by a roughing pump. The chamber is equipped with four $0.9 \mathrm{~m}$ diameter helium refrigerator cryopumps which will provide a xenon pumping speed in excess of $60,000 \mathrm{l} / \mathrm{s}$. The chamber has 2 test ports, one a $0.9 \mathrm{~m}$ diameter port with a $1.1 \mathrm{~m}$ long spool piece and an isolation valve, and the other a $0.3 \mathrm{~m}$ diameter port with a $0.5 \mathrm{~m}$ long spool piece and an isolation gate valve. The facility also has multiple $0.3 \mathrm{~m}$ and $0.6 \mathrm{~m}$ apertures for electrical penetrations, windows, and additional test ports.

- Plasma contactor performance stand - The existing tank 5 facility, which is used primarily for electric propulsion research, is also being utilized for performance tests of the plasma contactor and for assessing PCU plume plasma properties, optical emissions, and other radiated EMI in order to evaluate these critical SSF integration issues. The vacuum chamber is approximately $4.6 \mathrm{~m}$ in diameter by $18.3 \mathrm{~m}$ long and has a xenon pumping speed of approximately $230,000 \mathrm{\ell} / \mathrm{s}$, provided by twenty $0.9 \mathrm{~m}$ diameter oil diffusion pumps and a $15 \mathrm{~K}$ helium cryosurface of approximately $40 \mathrm{~m}^{2}$ area. 
PLASMA CONTACTOR TECHNOLOGY FOR SPACE STATION FREEDOM

Table I Plasma Contactor In-House Hardware Definition and Testing Task

\begin{tabular}{|c|c|c|c|}
\hline $\begin{array}{l}\text { plasma contactor } \\
\text { system component }\end{array}$ & function & key technology issues & $\begin{array}{l}\text { development } \\
\text { status* }\end{array}$ \\
\hline $\begin{array}{c}\text { plasma contactor } \\
\text { unit } \\
\{\mathrm{PCU}\}\end{array}$ & $\begin{array}{l}\text { provides electron return } \\
\text { current to control SSF } \\
\text { potential }\end{array}$ & $\begin{array}{c}\text { - lifetime } \\
\text { - environmental effects on } \\
\text { performance } \\
\text { - uncertainties in key parameters - } \\
\text { range and variation in electron current } \\
\text { ion production } \\
\text { • issues of scale }\end{array}$ & $\begin{array}{l}\text { engineering } \\
\text { model }\end{array}$ \\
\hline $\begin{array}{l}\text { power electronics } \\
\text { unit } \\
\{\text { PEU }\}\end{array}$ & $\begin{array}{l}\text { - provides command/control/ } \\
\text { and telemetry interface } \\
\text { to contactor system ORU } \\
\text { - converts } 120 \text { VDC } \\
\text { SSF power to levels needed by } \\
\text { PCU and EMU } \\
\text { - activates, ignites, and } \\
\text { maintains PCU operation } \\
\text { - detects and resolves faults }\end{array}$ & $\begin{array}{l}\text { - critical interfaces } \\
\text { - EM compatibility } \\
\text { - fault detection and resolution }\end{array}$ & $\begin{array}{l}\text { breadboard } \\
\text { model }\end{array}$ \\
\hline $\begin{array}{l}\text { expellant } \\
\text { management unit } \\
\{\text { EMU }\}\end{array}$ & $\begin{array}{l}\text { - provides regulated flow } \\
\text { of xenon gas to PCU }\end{array}$ & $\begin{array}{l}\text { - contamination control and flight } \\
\text { integration } \\
\text { - flow control approach }\end{array}$ & $\begin{array}{l}\text { breadboard } \\
\text { model }\end{array}$ \\
\hline $\begin{array}{l}\text { orbit replaceable } \\
\text { unit } \\
\{\text { ORU }\}\end{array}$ & $\begin{array}{c}\text {-provides mechanical, } \\
\text { electrical, command/control/ } \\
\text { telemetry,and thermal interface } \\
\text { between contactor system and SSF } \\
\text { - provides micrometeroid } \\
\text { protection }\end{array}$ & - & - \\
\hline
\end{tabular}

*Indicates highest hardware development status that will be completed under existing in-house definition and testing task. 
PLASMA CONTACTOR TECHNOLOGY FOR SPACE STATION FREEDOM

Table II Plasma Contactor System Operational Requirements

\begin{tabular}{|c|c|}
\hline attribute & requirement \\
\hline potential control & clamping voltage ${ }^{*} \leq 20$ volts at all emission currents \\
\hline $\begin{array}{l}\text { emission } \\
\text { current }\end{array}$ & $\begin{array}{l}\text { - electron current levels up to } 10 \mathrm{~A} \text { to space plasma } \\
\qquad \text { dynamically variable }\end{array}$ \\
\hline control mode & $\begin{array}{l}\text { - steady-state operation for } 8800 \mathrm{~h} / \mathrm{yr} \\
\text { - } 6000 \text { 'IDLE' to 'CLAMPING' emission cycles/yr } \\
\text { - autonomous operational capability }\end{array}$ \\
\hline lifetime & $13,000-17,500 \mathrm{~h}$ \\
\hline performance & minimize power and expellant consumption \\
\hline system reliability & single-fault tolerant \\
\hline interfaces & $\begin{array}{c}\text { - compatible with all SSF utilities - power, data management, thermal, etc. } \\
\text { • robotically serviceable }\end{array}$ \\
\hline instrumentation & $\begin{array}{l}\text { - health monitoring } \\
\text { - measurement of plasma return current }\end{array}$ \\
\hline
\end{tabular}

*Clamping voltage refers to potential difference between cathode common of PCU and ambient space plasma potential. 


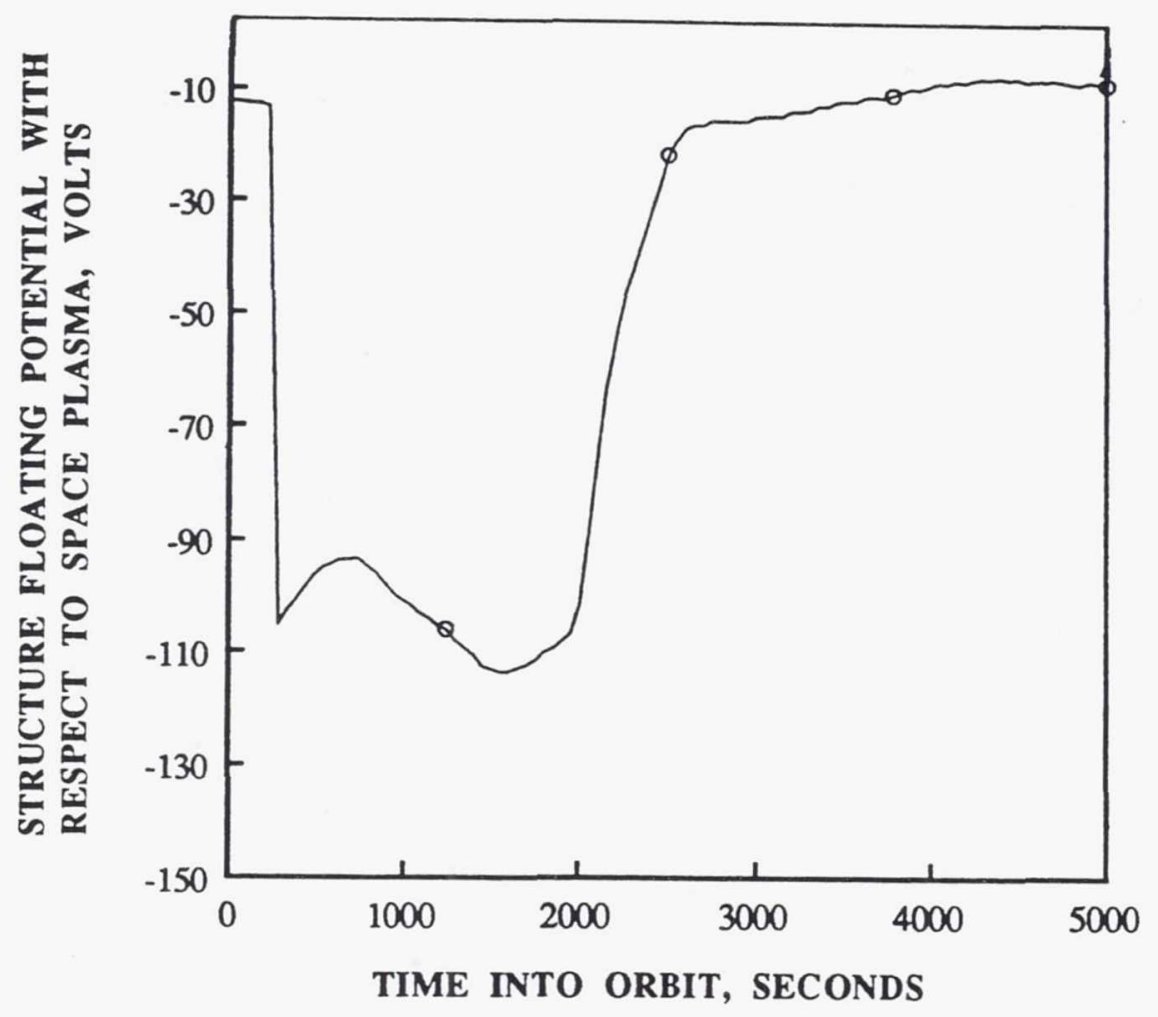

Fig. 1 Predicted negative floating potentials of SSF structure during mission build 5 \{without plasma contactor system\}, from Ref. 1.

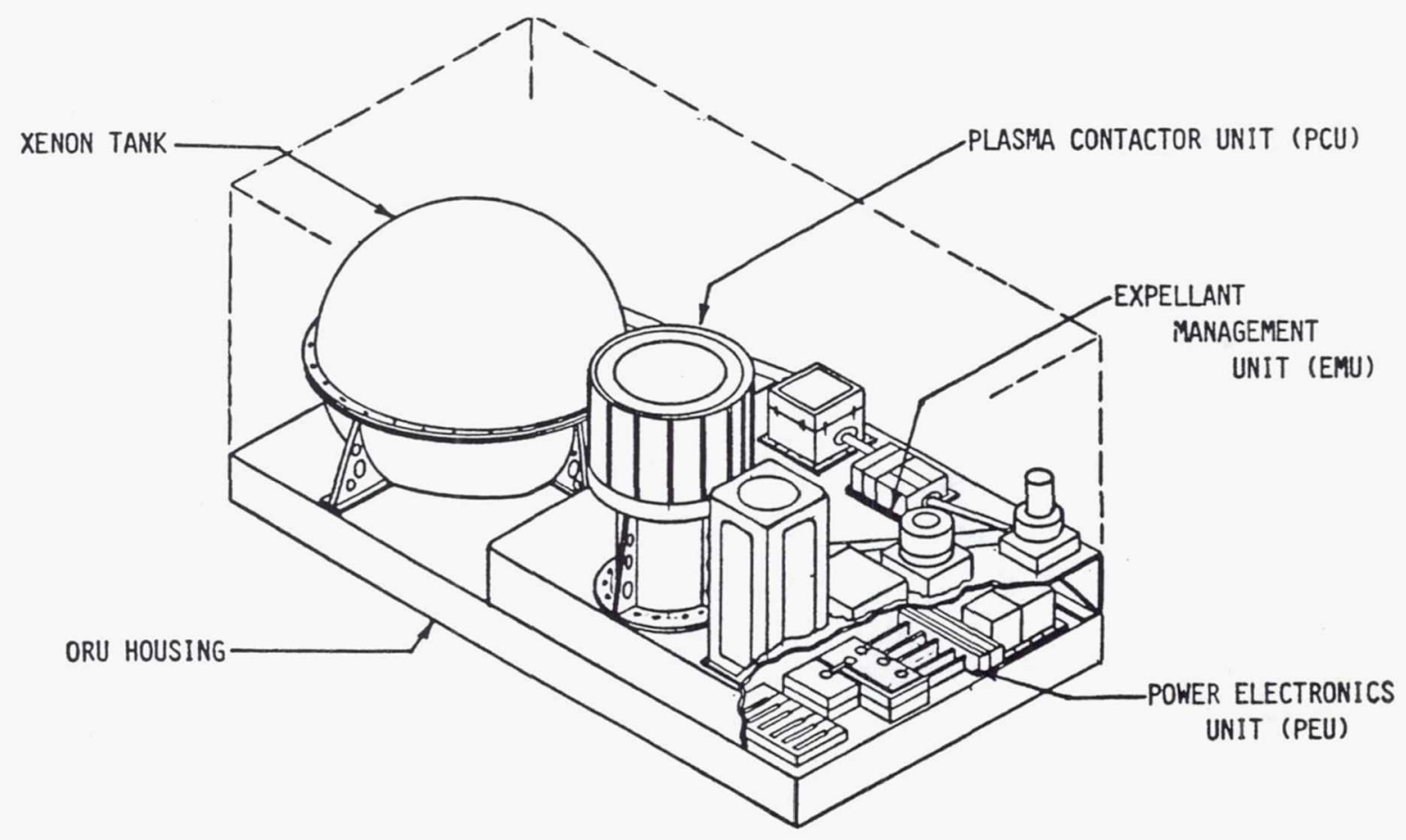

Fig. 2 Plasma contactor system conceptual design. 


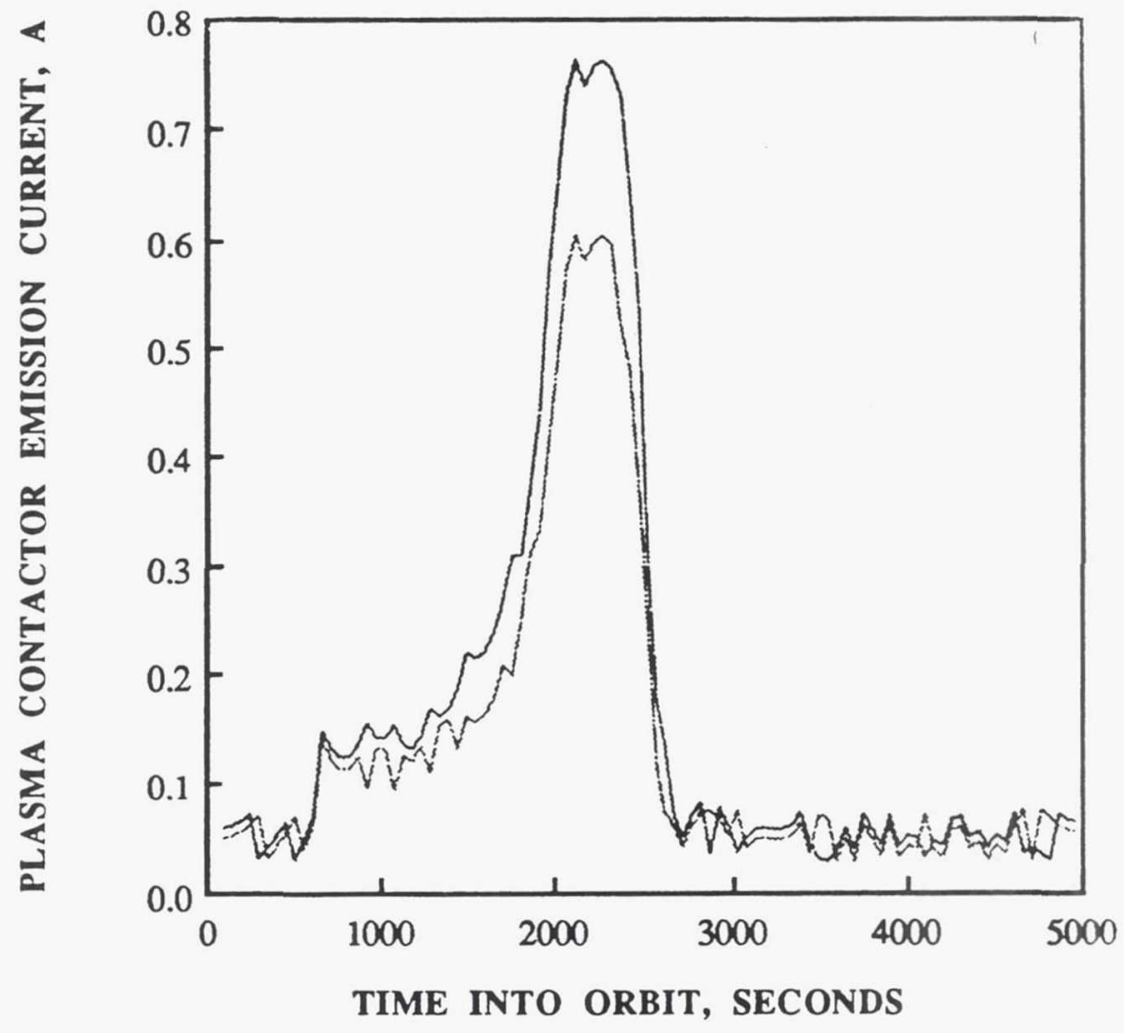

Fig. 3 Predicted plasma contactor emission current required for single-orbit during mission build 6 \{solar maximum conditions\}, from Ref. 19.

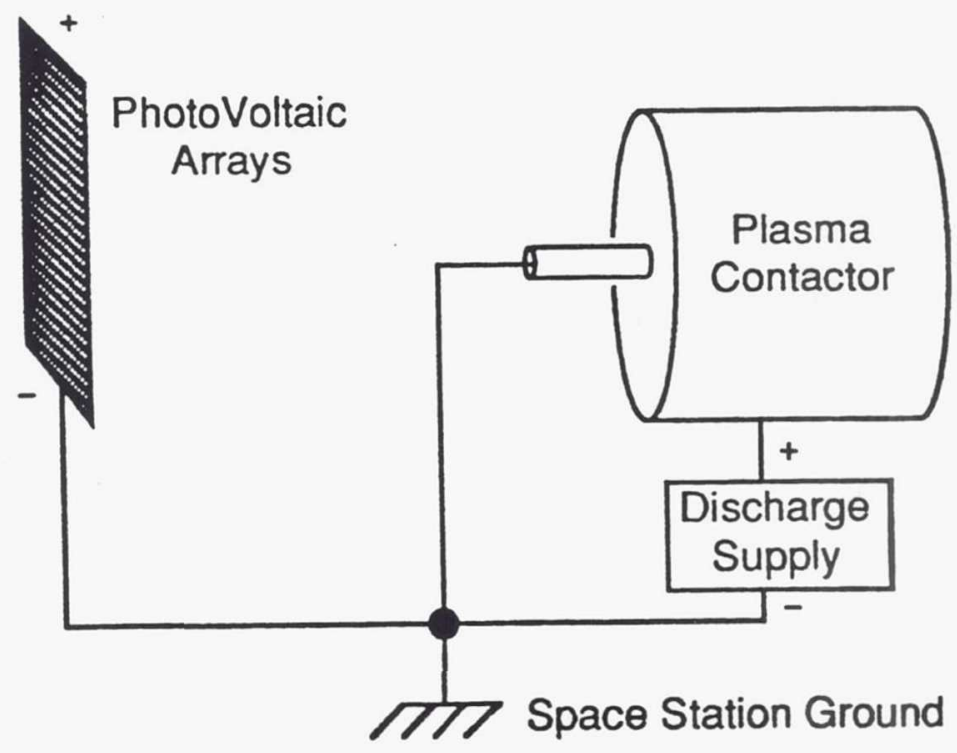

Fig. 4 Simplified plasma contactor unit/SSF electrical schematic. 


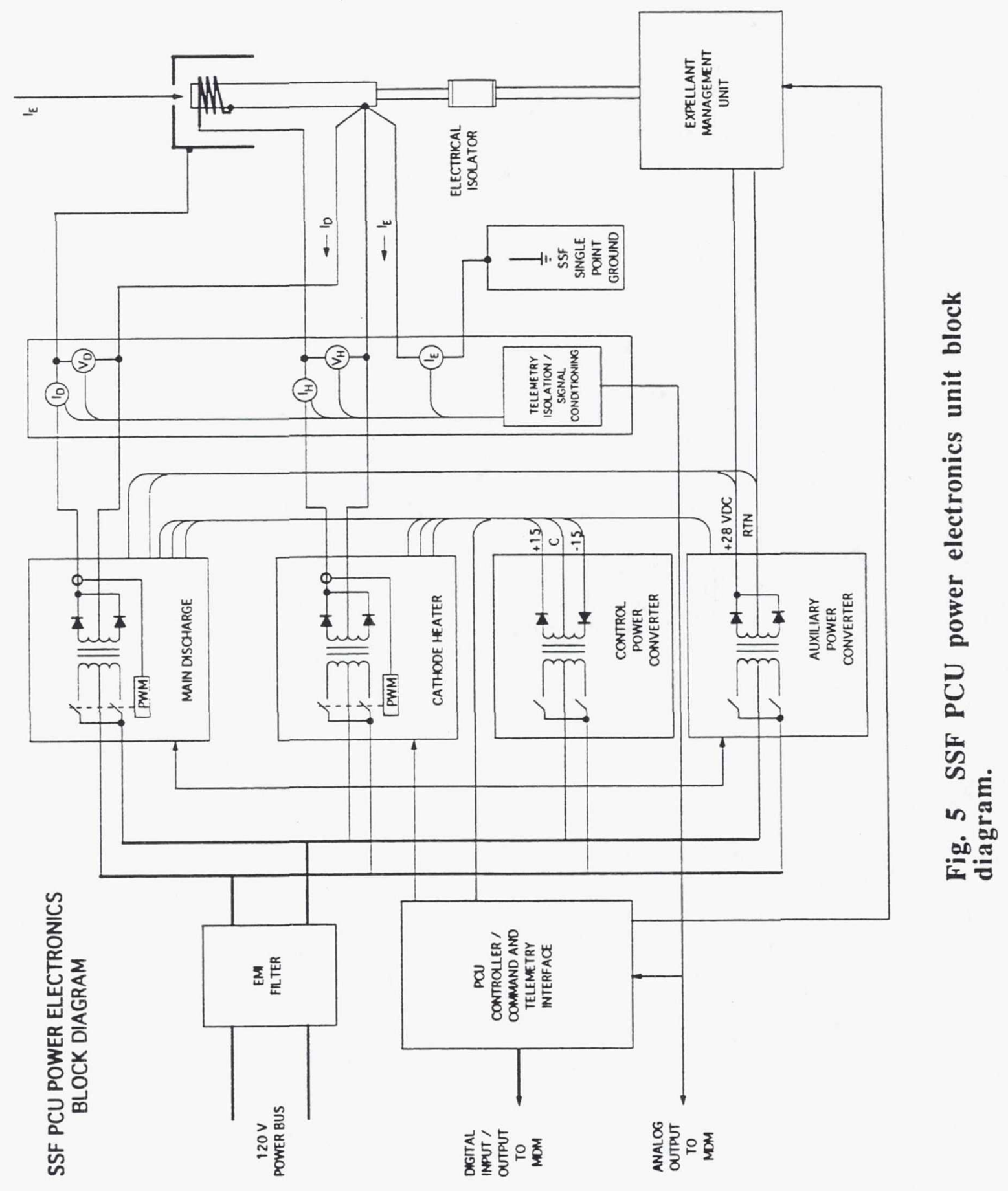




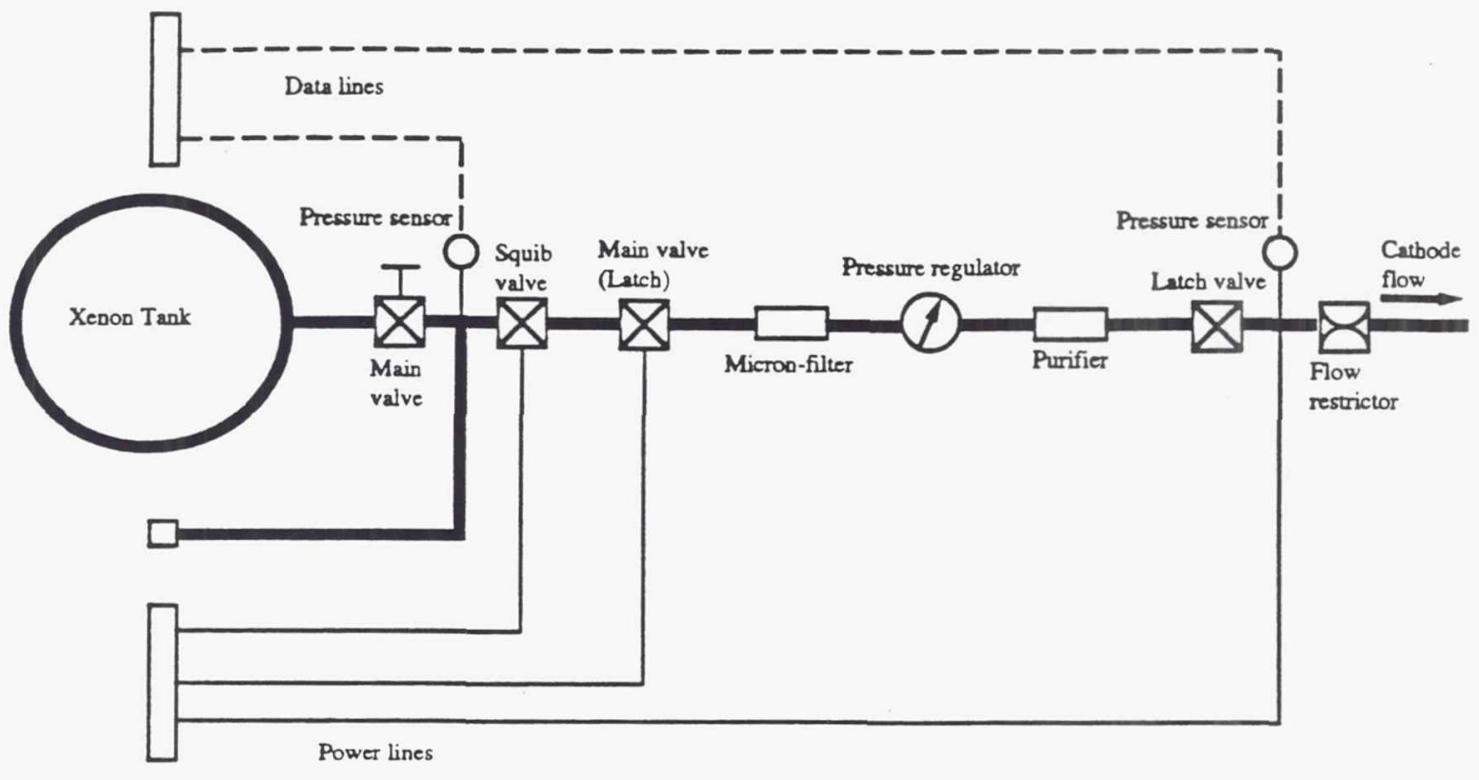

Fig. 6 SSF PCU expellant management unit conceptual design.

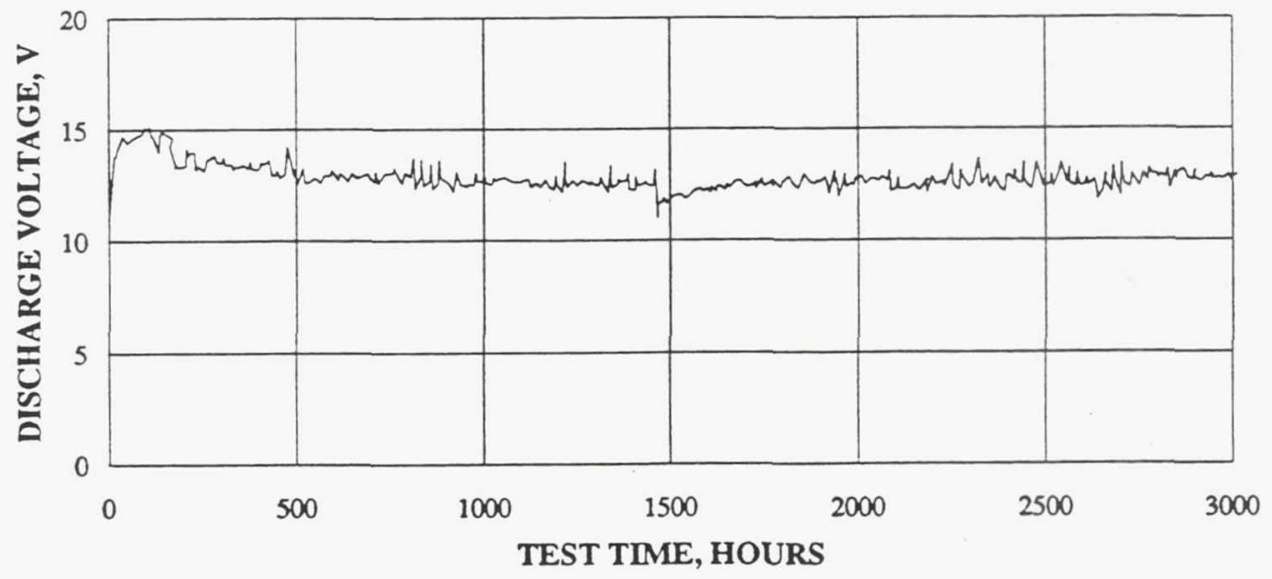

Fig. 7 Anode voltage versus time for high current hollow cathode wear test. 


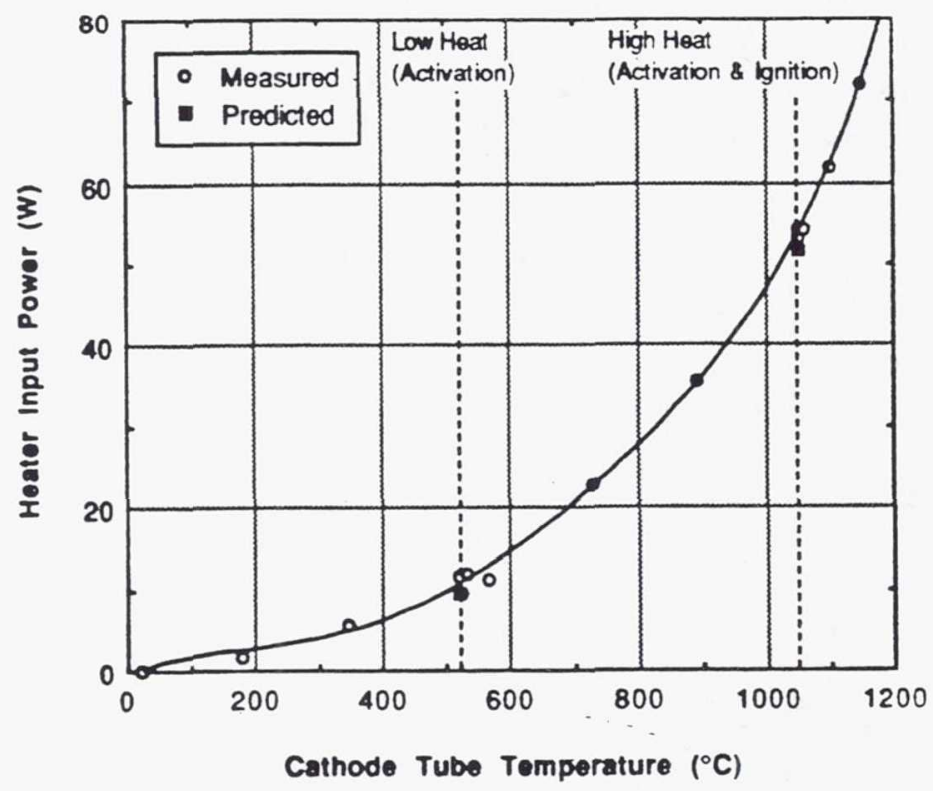

Fig. 8 Typical PCU hollow cathode heater performance.

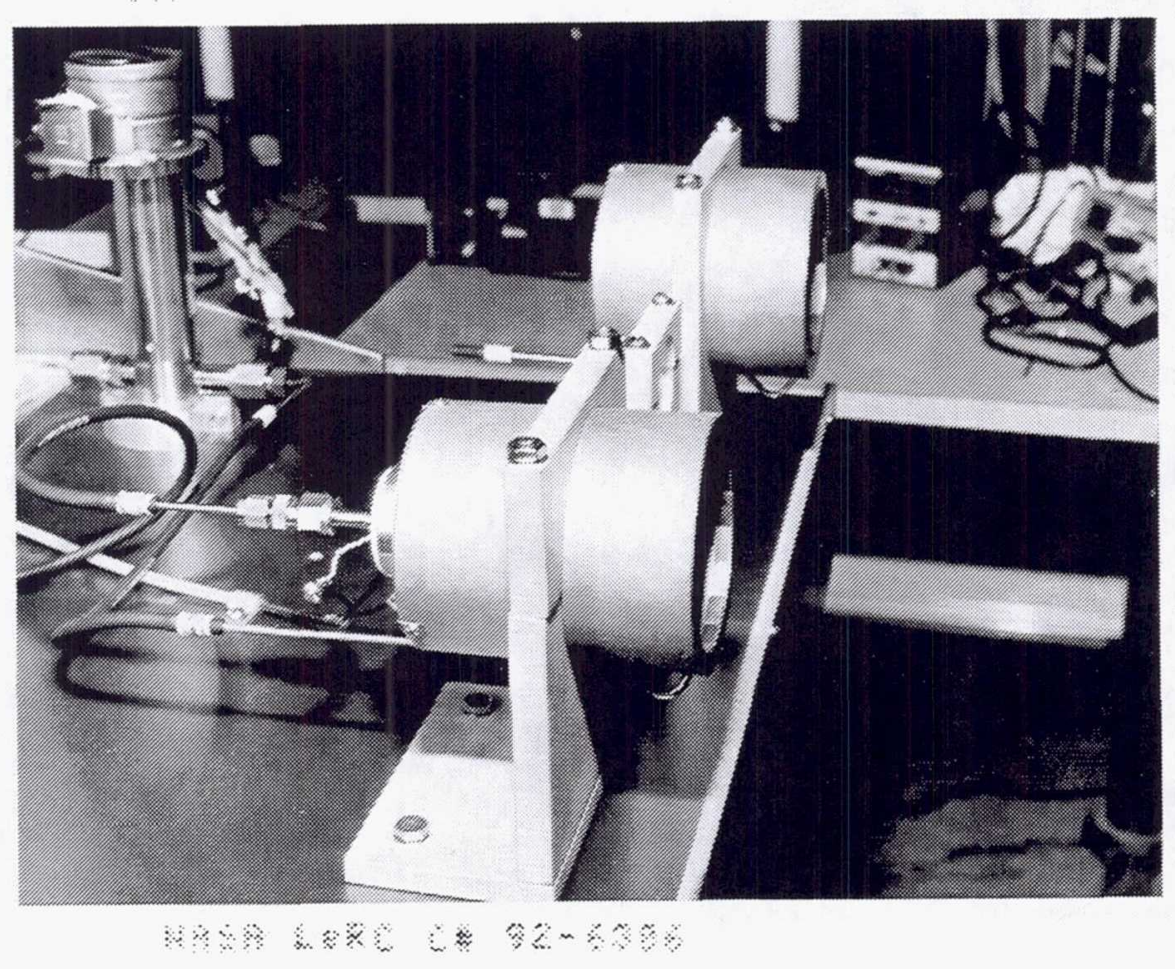

Fig. 9 Prototype plasma contactor units on test stand. 


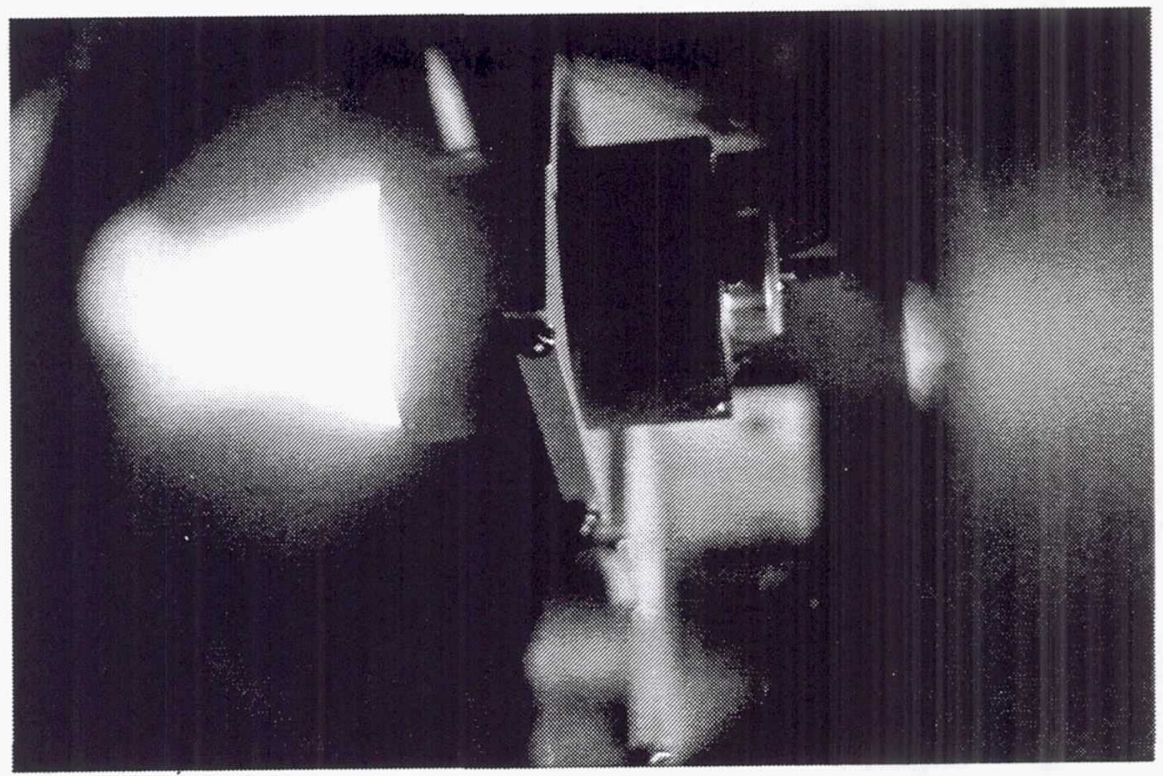

Fig. 10 Prototype plasma contactor unit operating at high emission current clamping mode.

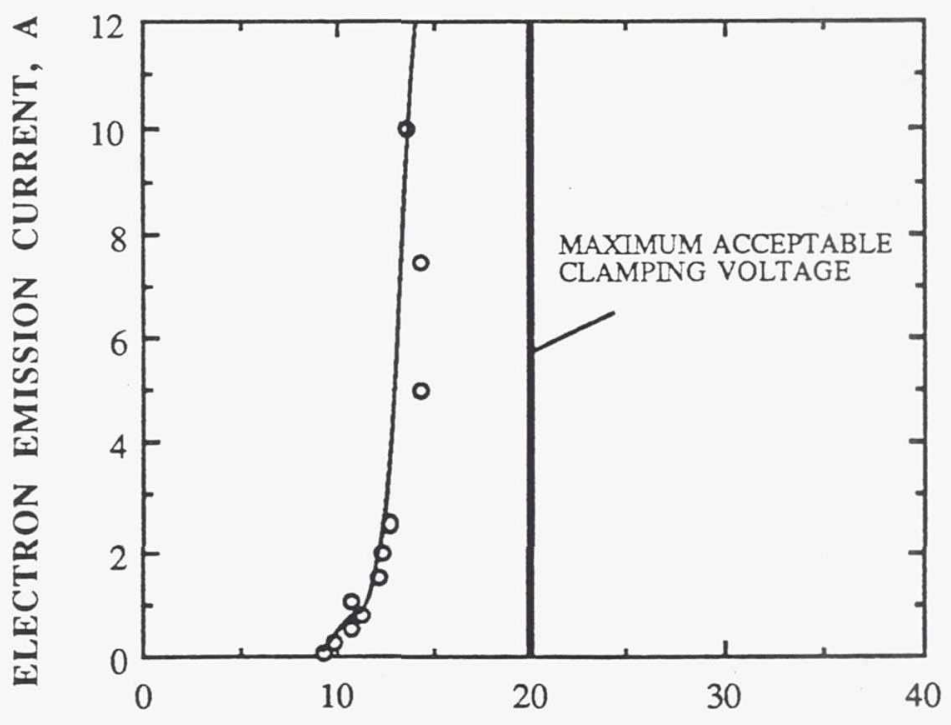

CLAMPING VOLTAGE, $\mathrm{V}$ \{potential difference between PCU cathode and external collector\}

Fig. 11 Typical prototype plasma contactor unit performance characteristic. 


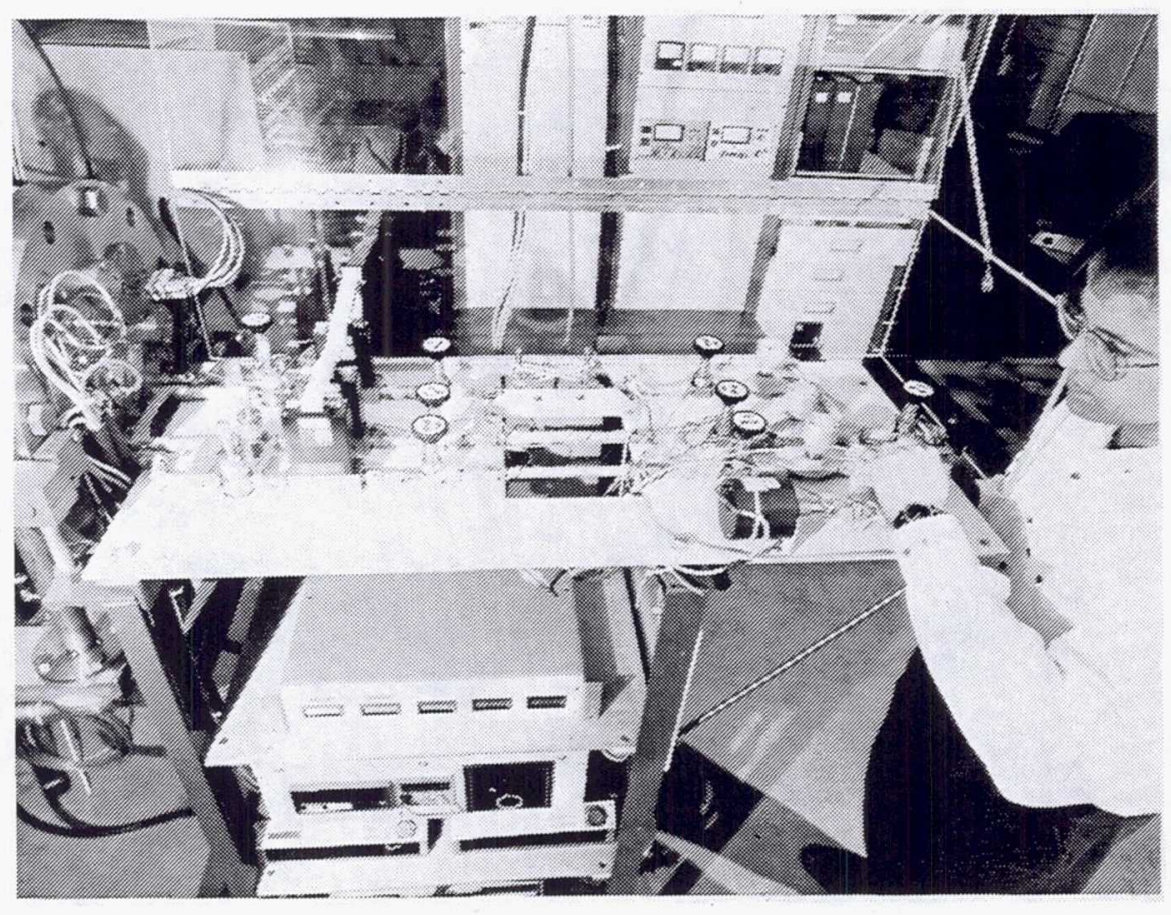

Fig. 12 Xenon feed system at test stand.

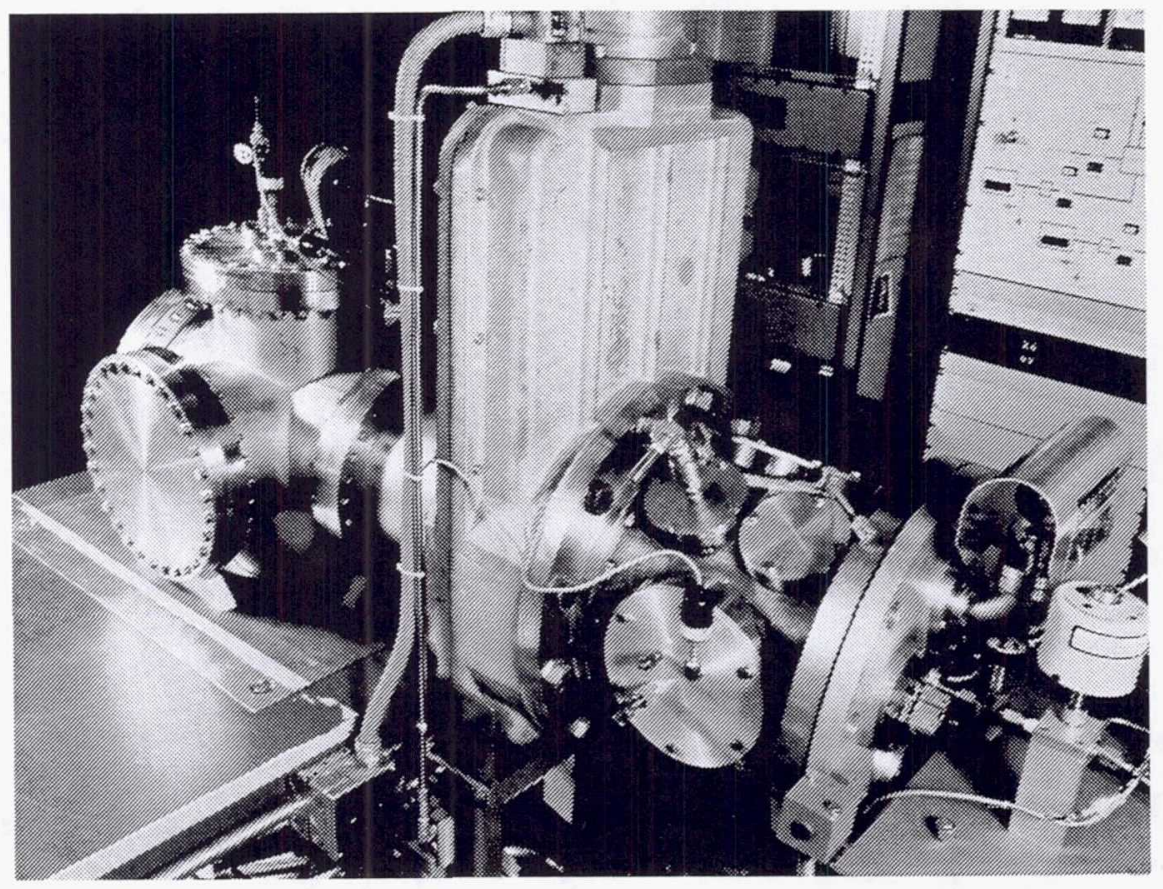

Fig. A1 Hollow cathode wear test stand. 


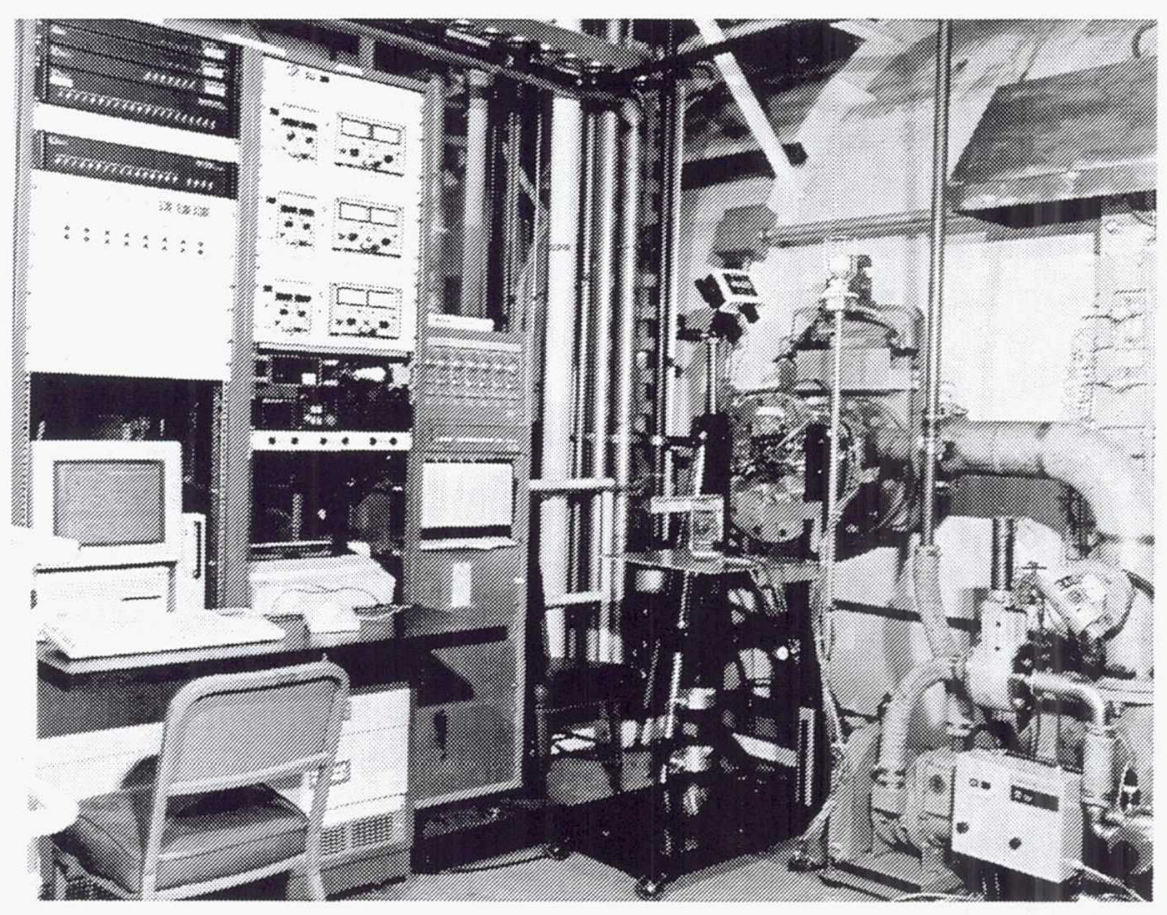

Fig. A2 Heater test stand.

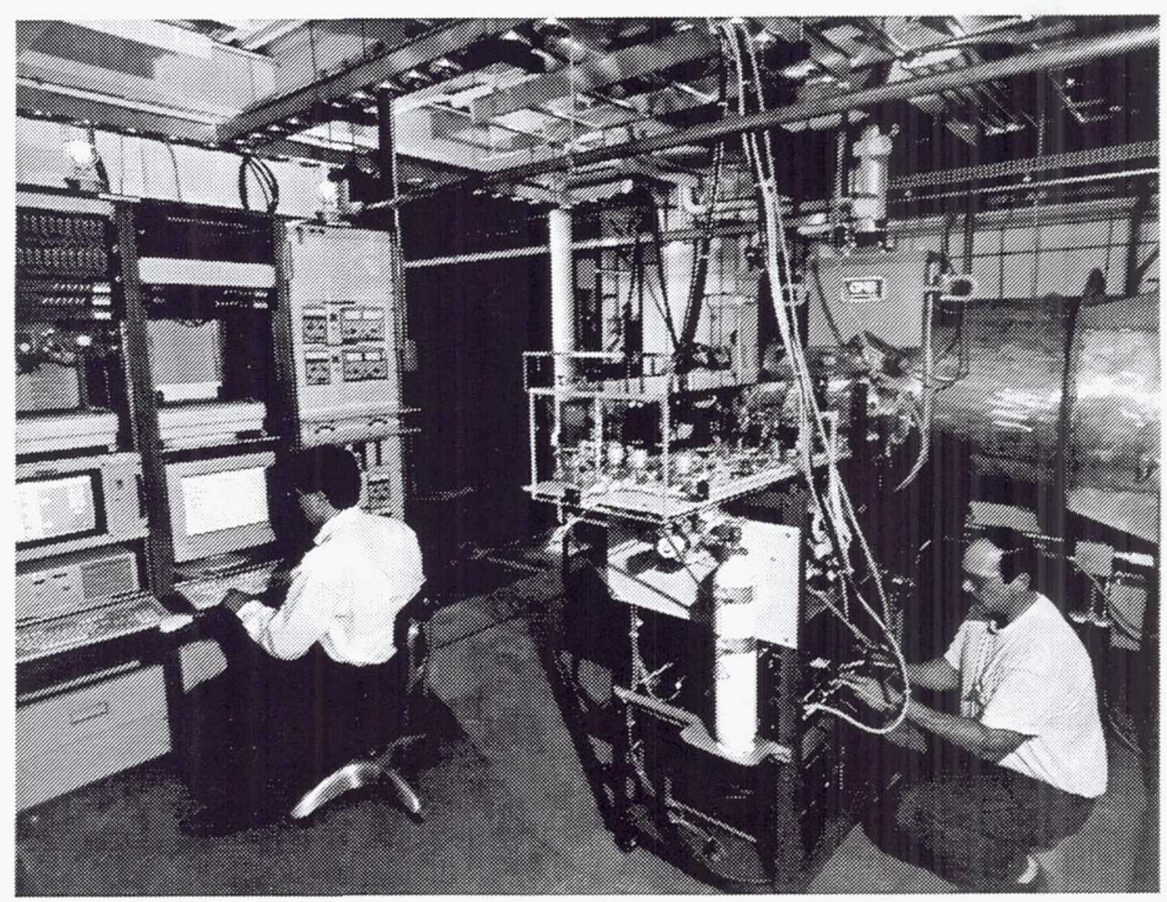

Fig. A3 Hollow cathode and PCU life test stand. 


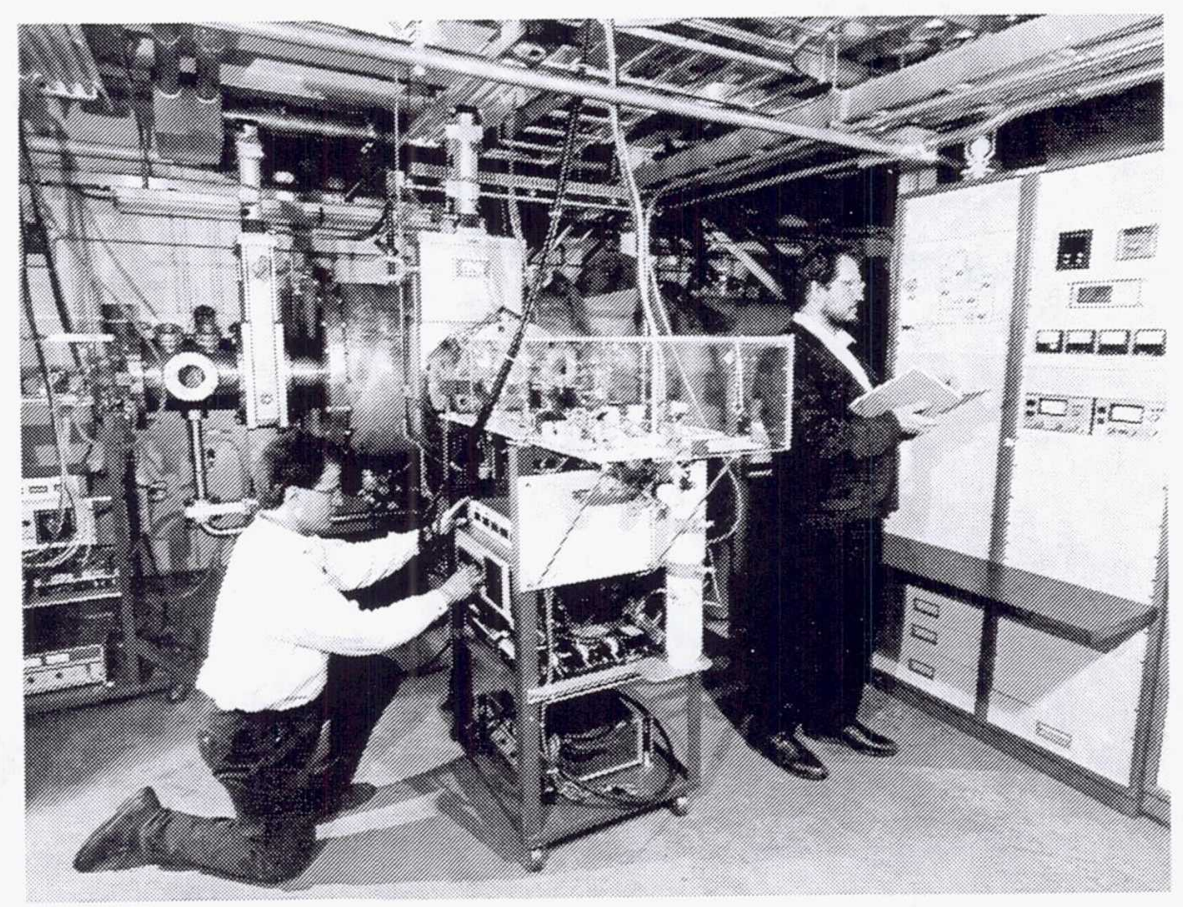

Fig. A4 Hollow cathode and PCU life test stand. 


\begin{tabular}{|c|c|c|c|c|}
\hline \multicolumn{3}{|c|}{ REPORT DOCUMENTATION PAGE } & & $\begin{array}{l}\text { Form Approved } \\
\text { OMB No. 0704-0188 }\end{array}$ \\
\hline \multicolumn{5}{|c|}{ 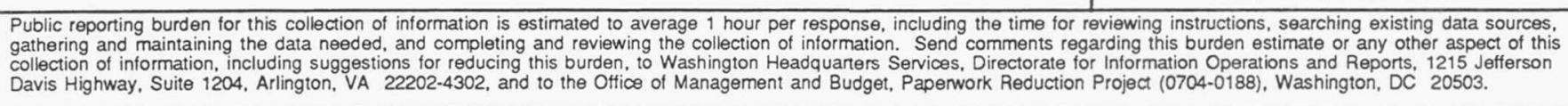 } \\
\hline 1. AGENCY USE ONLY (Leave blank) & $\begin{array}{r}\text { 2. REPORT DATE } \\
\text { June } 1993\end{array}$ & \multicolumn{3}{|c|}{$\begin{array}{l}\text { 3. REPORT TYPE AND DATES COVERED } \\
\text { Technical Memorandum }\end{array}$} \\
\hline \multicolumn{3}{|c|}{$\begin{array}{l}\text { 4. TITLE AND SUBTITLE } \\
\text { Plasma Contractor Technology for Space Station Freedom }\end{array}$} & \multicolumn{2}{|c|}{ 5. FUNDING NUMBERS } \\
\hline \multicolumn{3}{|c|}{$\begin{array}{l}\text { Michael J. Patterson, John A. Hamley, Timothy Sarver-Verhey, George C. Soulas, } \\
\text { James Parkes, Wayne L. Ohlinger, Michael S. Schaffner, and Amy Nelson }\end{array}$} & \multicolumn{2}{|c|}{ WU-474-46-10 } \\
\hline $\begin{array}{l}\text { 7. PERFORMING ORGANIZATIOI } \\
\text { National Aeronautics and } \\
\text { Lewis Research Center } \\
\text { Cleveland, Ohio } 44135\end{array}$ & $\begin{array}{l}\text { VAME(S) AND ADDRESS(ES) } \\
\text { Space Administration } \\
191\end{array}$ & & \multicolumn{2}{|c|}{ E-8028 } \\
\hline \multicolumn{3}{|c|}{$\begin{array}{l}\text { National Aeronautics and Space Administration } \\
\text { Washington, D.C. } 20546-0001\end{array}$} & \multicolumn{2}{|c|}{$\begin{array}{l}\text { NASA TM-106291 } \\
\text { AIAA-93-2228 }\end{array}$} \\
\hline \multicolumn{5}{|c|}{$\begin{array}{l}\text { 11. SUPPLEMENTARY NOTES } \\
\text { Prepared for the 29th Joint Propulsion Conference and Exhibit cosponsored by the AIAA, SAE, ASME, and ASEE, } \\
\text { Monterey, California, June 28-30, 1993. Michael J. Patterson and John A. Hamley, NASA Lewis Research Center; } \\
\text { Timothy Sarver-Verhey, George C. Soulas, and James Parkes, Sverdrup Technology, Inc. Lewis Research Center }\end{array}$} \\
\hline \multicolumn{3}{|c|}{$\begin{array}{l}\text { 12a. DISTRIBUTION/AVAILABILITY STATEMENT } \\
\text { Unclassified - Unlimited } \\
\text { Subject Category } 20\end{array}$} & \multicolumn{2}{|c|}{ 12b. DISTRIBUTION CODE } \\
\hline \multicolumn{5}{|c|}{$\begin{array}{l}\text { potentials of surfaces to eliminate/mitigate damaging inte } \\
\text { a dual-use technology which is a direct outgrowth of the I } \\
\text { technology development effort on ion thruster systems. S } \\
\text { tion of the contactor, validating its required lifetime, and } \\
\text { interference. The plasma contactor subsystems include th } \\
\text { expellant management unit. Under this program these wil } \\
\text { development status. New test facilities have been develop } \\
\text { characterizations and life testing of contactor components } \\
\text { and status of the plasma contactor hardware development } \\
\text { system components. }\end{array}$} \\
\hline \multirow{2}{*}{\multicolumn{2}{|c|}{$\begin{array}{l}\text { 14. SUBJECT TERMS } \\
\text { Space Station Freedom, Plasma contactors }\end{array}$}} & & & $\begin{array}{l}\text { 15. NUMBER OF PAGES } \\
22 \\
\end{array}$ \\
\hline & & & & $\begin{array}{l}\text { 16. PRICE CODE } \\
\text { A03 }\end{array}$ \\
\hline $\begin{array}{l}\text { 17. SECURITY CLASSIFICATION } \\
\text { OF REPORT } \\
\text { Unclassified }\end{array}$ & $\begin{array}{l}\text { 18. SECURITY CLASSIFICATION } \\
\text { OF THIS PAGE } \\
\text { Unclassified }\end{array}$ & $\begin{array}{l}\text { 19. SECURITY CLASSIFICA } \\
\text { OF ABSTRACT } \\
\text { Unclassified }\end{array}$ & ITION & 20. LIMITATION OF ABSTRACT \\
\hline NSN 7540-01-280-5500 & 21 & & & $\begin{array}{l}\text { andard Form } 298 \text { (Rev. 2-89) } \\
\text { scribed by ANSI Std. Z39-18 } \\
\text { s-102 }\end{array}$ \\
\hline
\end{tabular}




\section{Supplementary Notes}

Group, 2001 Aerospace Parkway, Brook Park, Ohio 44142; Wayne L. Ohlinger, Georgia Technical Research Institute, Atlanta, Georgia 30332; Michael S. Schaffner, Cleveland State University, Department of Engineering, Cleveland, Ohio 44114; and Amy Nelson, Purdue University, Department of Physics, West Lafayette, Indiana 47907. Responsible person, Michael J. Patterson, (216) 433-7481. 